\title{
Początki syjonizmu w Tarnowie. Współpraca i konflikt z Teodorem Herzlem
}

\author{
Leszek Hońdo
}

Uniwersytet Jagielloński w Krakowie - Instytut Judaistyki

Adres do korespondencji: leszek.hondo@uj.edu.pl

Historia artykułu:

Otrzymano: 29.06.2018

Zrecenzowano: 06.07.2018

Opublikowano: lipiec 2019

\begin{abstract}
Abstrakt
Od 1896 r. rozpoczęła się współpraca tarnowskich syjonistów z Teodorem Herzlem, choć zdania na temat książki Judenstaat były wśród nich podzielone. Na zjeździe galicyjskich syjonistów w październiku 1896 r. podjęto rezolucję o poparciu idei przedstawionych w książce. W styczniu 1897 r. odbyło się pierwsze spotkanie Abrahama Salza (lidera syjonistów w Tarnowie i całej Galicji) z T. Herzlem, podczas którego został przedstawiony stan ruchu na terenie Galicji. Odbyły się następne spotkania, podczas których przygotowywano się do zwołania światowej konferencji. Ustalono między innymi, że galicyjscy syjoniści przywiozą na kongres podpisy galicyjskich Żydów z oświadczeniami o gotowości przesiedlenia się do Palestyny w akcji zapoczątkowanej przez Herzla.

W czasie I kongresu syjonistów w Bazylei A. Salz został wybrany II wiceprzewodniczącym tego kongresu. Wygłosił o referat o położeniu Żydów w Galicji. W trakcie kongresu ścierały się dwie frakcje. Zwolennicy Herzla stanowczo sprzeciwiali się drobnej i skrytej kolonizacji Palestyny, zanim nie uzyska się gwarancji politycznych. Druga opcja opowiadała się za dalszą kolonizacją, za którą optowała większość syjonistów z Galicji. Pomimo przyjętego programu bazylejskiego, zgodnego z poglądami Herzla, syjoniści z Tarnowa pojechali zaraz po kongresie do Paryża i zakupili grunt pod kolonię nazywaną Machnajim. Na tym tle doszło do konfliktu Salza z Herzlem, który sprzeciwiał się doraźnej kolonizacji. Konflikt został załagodzony uznaniem osiedla w Palestynie za „stację próbną”. Jednak nastąpiło oziębienie stosunków, gdyż każda ze stron broniła swoich racji.
\end{abstract}

Słowa kluczowe: historia Żydów, syjonizm, syjonizm w Tarnowie, Żydzi w Galicji, Żydzi w Tarnowie

\section{Wstęp}

Ruch syjonistyczny w Galicji i samym Tarnowie pojawił się niemal równocześnie $\mathrm{z}$ powstaniem podobnych ugrupowań w Wiedniu1. Działania pierwszych syjonistów w tym mieście wzniosły znaczący wkład w rozwój tego ruchu. Niektóre ważne wydarzenia zostały utrwalone z okazji obchodzonej w 1934 roku pięćdziesięciu lat historii syjonizmu². Początki syjonizmu w Tarnowie zostały opisane w pracy Natana M. Gelbe-

1. Największy wpływ na rozwój syjonizmu w Austrii miał powstały późną jesienią 1882 roku akademicki związek „Kadmiah” (Akamdemischer Verein). Należy jednak stwierdzić, że ważną rolę odgrywały w nim osoby pochodzące właśnie z Galicji. Większość jego założycieli pochodziła właśnie stamtąd. Nie zabrakło wśród nich osób z Tarnowa; por. A. Gaisbauer, Davidstern und Doppeladler: Zionismus und jüdischer Nationalismus in Österreich 1882-1918, Wien 1988, s. 46.

2. Pięćdziesiąt lat sjonizmu, 1884-1934. Jubileuszowa księga pamiątkowa, Tarnów 1934. $\mathrm{ra}^{3}$. Na temat historii syjonizmu w Tarnowie i udziału tarnowskich syjonistów w światowym ruchu można znaleźć w dwóch pracach odnoszących się do zagłady tarnowskich Żydów. Ukazały się one w Izraelu; pierwsza pod redakcją Abrahama Chometa - Tarnów: Istnienie i zagłada żydowskiego miasta ${ }^{4}$, druga - także pod redakcją Chometa oraz Józefa Korniły - Tarnów. Księga pamięci ${ }^{5}$. Ogólne informacje na temat syjonizmu galicyjskiego przedstawił Filip Friedman ${ }^{6}$ oraz Ignacy Schipper ${ }^{7}$.

3. N.M. Gelber, תולדות התנועה הצירנית בגליציה [Historia ruchu syjonistycznego w Galicji], 1918-1875, Jerusalem 1958.

4. טארנע מקיום ארן חורבן פון א ירדישער שטאט, [Tarnów: istnienie i zagłada żydowskiego miasta], red. A. Chomet, Tel Awiw 1954.

5. טרנוב - טארנע, ספר זכרון, [Tarnów, Księga Pamięci], red. A. Chomet, J. Korniło Tel Awiw 1968.

6. F. Friedman, Dzieje Żydów w Galicji, [w:] A. Hafftka, I. Schiper, A. Tartakower (red.): Żydzi w Polsce Odrodzonej, Warszawa, t. II: 1933, s. 385-412.

7. I. Schiper, Dzieje sjonizmu na ziemiach polskich (do 1918 r.), [w:] A. Hafftka, I. Schiper, A. Tartakower (red.): Żydzi w Polsce Odrodzonej, Warszawa, t. II: 1933, s. 518-530. 


\section{Początki syjonizmu w Tarnowie}

W roku 1934 tarnowscy syjoniści obchodzili 50-lecie swojej działalności. Jako początek działalności tego ruchu w mieście uznano wstąpienie w 1884 roku tarnowian Abrahama Salza ${ }^{8}$, Edwarda Schwagera ${ }^{9}$ i Zygmunta Bytkowskiego-Bromberga ${ }^{10}$ do założonego w 1882 roku w Wiedniu, syjonistycznego stowarzyszenia studentów „Kadimah”. Przeprowadzili oni w Tarnowie zbiórkę książek i wysłali do centrali do Wiednia ${ }^{11}$. Wyjazd Salza i Bromberga na studia do Wiednia i Schwagera do Krakowa ograniczył działalność syjonistyczną. Była to w zasadzie działalność agitacyjna Schwagera w czasie wizyt w Tarnowie podczas przerw w nauce. Odbywała się ona w czytelni „Stowarzyszenia Młodzieży Starozakonnej”12. W wyniku tej działalności w roku 1887 „Stowarzyszenie Młodzieży Starozakonnej” oficjalnie zerwało z dążeniami asymilatorskimi i zmieniło nazwę na „Czytelnia Młodzieży Handlowej” (Leseverein der Handelsjugend). Właściwa praca rozpoczęła się dopiero po skończeniu studiów A. Salza w roku 1887, który przemawiał w Tarnowie 18 XII 1887 roku na pierwszym w Galicji wieczorku machabeuszowskim $^{13}$. W roku 1888 zostało założone pierwsze w Tarnowie syjonistyczne stowarzyszenie „Hatechija”, którego celem było kolonizacja w Palestynie. Stowarzyszenie propagowało ideę kolonizacji Palestyny i szukało finansowego wsparcia dla przyszłych kolonistów. Stowarzyszenie to posiadało własny lokal, w którym odbywały się zebrania i dyskusje na temat syjonizmu.

8. Abraham Salz (1864-1941), adwokat, lider ruchu syjonistycznego w Galicji w końcu XIX w. Ukończył prawo na uniwersytecie w Wiedniu. Od 1887 r. w Tarnowie aktywnie działał w ruchu syjonistycznym. W 1893 r. na I zjeździe organizacji syjonistycznych w Galicji, który odbył się we Lwowie, wybrany na prezydenta Centralnego Komitetu Wykonawczego Narodowej Partii Żydowskiej w Galicji. Współzałożyciel (1897 prezes) Galicyjskiego Towarzystwa dla Prac Kolonizacyjnych w Palestynie „Ahawat Zion” z siedzibą w Tarnowie. Autor pracy: Jaki powinien być stosunek Żydów do Polaków (1892) i wspomnień z okazji 50-lecia ruchu syjonistycznego w Tarnowie (1934). Pochowany na cmentarzu żydowskim w Tarnowie.

9. Edward Dawid Schwager (1867-?), adwokat, jeden z liderów syjonistów w Tarnowie. Ukończył prawo na UJ. Uczestniczył jako delegat z Tarnowa w I kongresie syjonistycznym w Bazylei w $1897 \mathrm{r}$.

10. Zygmunt Bytkowski-Bromberg (1866-1923), poeta, historyk literatury i działacz syjonistyczny. Ur. w Stryju. Ukończył gimnazjum w Tarnowie. Z ramienia Ahawat Zion uczestniczył w I kongresie syjonistycznym w Bazylei w 1897 r. Od 1898 r. organizował pierwszą kolonię Żydów z Galicji Machnajim w Galilei. Po powrocie do Galicji ukończył studia filozoficzne na uniwersytecie lwowskim i objął posadę nauczyciela w tym mieście. Autor wierszy i licznych przekładów. Najbardziej znany poetycki przekład Pieśni nad pieśniami; jego biogram: Zygmunt Bytkowski-Bromberg, opr. M. Bałaban, w: Polski Słownik Biograficzny, Kraków 1937, t. III, s. 184.

11. Pięćdziesiąt lat sjonizmu, s. 7.

12. O jej początkach wspomina E. Schwager w liście do A. Salza z 2 XII 1884 r.; por. A. Chomet, Zdarzenia i ludzie, w: Pięćdziesiąt lat sjonizmu, s. 82.

13. A. Chomet, Nasz hołd, w: Pięćdziesiąt lat sjonizmu, s. 4; por. „Pogoń", 1888 z 1 I.
Od początku lat 90. pojawiły się próby utworzenia wspólnej organizacji obejmującej zasięgiem całą Galicję. W roku 1891 odbyły się we Lwowie i Tarnowie pierwsze wspólne spotkania, których celem było wypracowanie form organizacyjnych stowarzyszeń syjonistycznych na obszarze Galicji ${ }^{14}$. W wyniku ustaleń stowarzyszenie „Hatechija” w Tarnowie została zmieniona na „Zion” (podobnie było w innych miastach) i połączyło się z innymi stowarzyszeniami w Galicji tworząc jeden związek. Jego centralą został Tarnów. Od 1892 roku syjoniści w Galicji zaczęli wydawać polskojęzyczny dwutygodnik „Przyszłość”"15. W dniach 23-24 IV 1893 roku we Lwowie odbyła się I konferencja syjonistów w Galicji. Jej program obejmował m.in. sprawozdanie $\mathrm{z}$ dotychczasowego rozwoju ruchu syjonistycznego w Galicji, omówienie zasad funkcjonowania narodowej partii żydowskiej i ruchu syjonistycznego. Władzą ustawodawczą dla ruchu został ustanowiony coroczny zjazd. Pracami zaś kierował Centralny Komitet Wykonawczy, którego prezydentem wybrano A. Salza. W dniach 2-4 IX 1894 roku odbyła się we Lwowie II konferencja Narodowej Partii Żydowskiej, w której wzięło udział 19 towarzystw z Galicji (w trakcie konferencji poinformowano o utworzeniu 8 nowych). W programie syjonistów znalazły się dwa cele: rozwiązanie kwestii żydowskiej przez założenie kolonii w Palestynie i Syrii oraz troska o polityczne, ekonomiczne i duchowe potrzeby Żydów w Galicji poprzez żydowską politykę w tym kraju ${ }^{16}$.

Powstałe w Tarnowie w sierpniu 1891 roku Galicyjskie Towarzystwo dla Prac Kolonizacyjnych w Palestynie w krótkim czasie zaczęło odgrywać decydująca rolę wśród towarzystw kolonizacyjnych w Galicji. Towarzystwo miało swoją siedzibę przy ul. Wekslarskiej $3^{17}$. W momencie zakładania towarzystwo liczyło 40 osób. Celem towarzystwa był zakup ziemi w Palestynie i wysłanie tam jednego z członków, na którego padnie los z pośród 100 innych, którzy zdecydowali się na emigrację do Palestyny. Założyciele podjęli akcję werbunkową członków także w innych miastach Galicji. 24 IV 1894 roku odbyło się w Tarnowie walne zgromadzenie towarzystwa. Otwarcia dokonał A. Salz. On także przedstawił zebranym sprawozdanie z działalności grupy tarnowskiej. Zdaniem Salza, jednym z sukcesów stowarzyszenia było wstąpienie w jego szeregi ok. 60 konserwatywnych Żydów. W wyborach do wydziału wyłoniono następujące władze: prezes Aron Safier, wiceprezes Abraham Salz, wydzia-

14. Pierwsze oficjalne spotkanie odbyło się we Lwowie 6 VI $1891 \mathrm{r}$.

15. Ukazywał się do 1900 r. W latach 1892-1895 był organem Narodowej Partii Żydowskiej. Od marca 1895 r. organem Towarzystwa Politycznego Żydów Galicyjskich i Bukowińskich, pozostając jednocześnie organem Narodowej Partii Żydowskiej. Na początku 1897 r. stał się organem syjonistów.

16. Zdaniem M. Ehrenpreisa to wyróżniało galicyjskich syjonistów z jednej strony od zachodnich syjonistów, z drugiej od rosyjskiego Chwewej Zion; por. M. Ehrenpreis, Vor Herzl un mit Herzl, [w:] Theodor Herzl Jahrbuch, (wyd.) T. Nussenblat, Wien 1937, s. 185.

17. „Przyszłość”, 1893, nr 4 (listopad). 
łowi: Berisch Maschler, Józef Feigenbaum, Eliasz Baron, Wolf Münz, J.H. Bard, S.M. Spira. Zastępcy wydziałowych: Israel Wolf i Abraham Ptasznik.

W roku 1896 zostały zatwierdzony statut stowarzyszenia kolonizacyjnego „Ahawat Zion” z siedzibą w Tarnowie, którego celem było: „założenie nowego osiedla w Palestynie i skolonizowanie go, o ile możliwości, Żydami pochodzącymi z Galicji”. Organami towarzystwa były: Doroczne Walne Zgromadzenie członków, Wydział Centralny, składający się z osób w różnych miastach zamieszkałych i Komitet Wykonawczy, składający się z członków Wydziału Centralnego zamieszkałych w Tarnowie ${ }^{18}$.

19-20 V 1897 roku odbyło się w Tarnowie walne zgromadzenie „Ahawat Zion” Towarzystwo liczyło około już 600 osób, w tym w samym Tarnowie 208. W zebraniu uczestniczyło 48 delegatów z całej Galicji oraz przedstawiciel wiedeńskiego związku (Verband), literat H. Jork-Steiner. ${ }^{19}$ Przybył na nie także sędziwy 80-letni rabin Feiwisz Schreier z Bohorodczan ${ }^{20}$, który został prezesem honorowym Walnego Zgromadzenia. W wyniku wyborów prezesem został B.A. Weiss, naczelny rabin w Czerniowcach. Kierującym prezesem A. Salz. Wydział Centralny tworzyli: Leon Spitz, Dawid Fast, dr J. Rost, Edward Schwager, Majer Holländer, Pinkas Basler, Zygmunt Bromberg (sekretarz), Z.M. Spira (hebr. sekretarz), Juliusz Hochfeld (Lwów), A. Apfelbaum (Rzeszów), Aron Markus (Podgórze), N. Neufeld (Jaworzno), dr S. Rossberger (Jarosław), E.H. Żupnik (redaktor, Drohobycz), Ch. Engelberg (Tarnów), I.S. Fuchs (redaktor Hamagid), Mendel Fränkel (Kraków), S. Melzer, E. Sterhell i A. Weidman (Rohatyn), M. Aschheim (Mielec), S. Schreiber (Seret), Pomeranz (Borysław), L. Taubes (Kołomyja). Jako zastępcy: Emil Broch, Ch.H. Lichtblau i M. Bienestock (Tarnów), dr H. Gabel (Lwów), L. Koretz (Ropczyce), A. Rosmarin (Łańcut) i M. Aschkenazy (Zbaraż). Walne Zgromadzenie wybrało delegatów na I Kongres, który miał być zwołany do Monachium.

\section{Współpraca tarnowskich syjonistów z Teodorem Herzlem}

Już od roku 1891 pojawiły się próby utworzenia ogólnoaustriackiego związku i włączenia do niego galicyjskich organizacji. Jednak dopiero na początku 1893 roku doszło do utworzenia związku kolonizacyjnego „Zion”, w którym uczestniczyły towarzystwa kolonizacyjne z Galicji, w tym z Tarnowa. W dniach 3-5 IX 1893 roku przedstawiciele syjonistów galicyjskich (Salz, M. Ehrenpreis) wzięli udział w zorganizowanej w Wiedniu pierwszej konferencji wstępnej mającej na celu zwołanie ogólnoświatowej konferencji syjonistycznej ${ }^{21}$. 1 XI 1893 roku od-

\footnotetext{
18. Pięćdziesiąt lat syjonizmu, s. 13.

19. Ibidem, s. 14.

20. Ibidem, s. 4.

21. M. Ehrenpreis, op. cit., s. 189-193.
}

było się w Krakowie spotkanie, zwołane i prowadzone przez N. Birnbauma i A. Salza, w którym wzięli udział delegaci nie tylko z galicyjskich miast (Kraków, Lemberg, Tarnów, Rzeszów), a także delegaci z Wiednia i Czech. Było to w zasadzie pierwszym ogóloaustriackiem syjonistycznym zjazdem. Jednak założona Żydowska Narodowa Partia Austrii (Jüdisch-nationale Partei Österreichs), posiadająca wybrane władze, w praktyce nie podjęła działalności.

Od roku 1896 rozpoczęła się współpraca galicyjskich syjonistów z T. Herzlem, choć wśród galicyjskich syjonistów zdania na temat książki Judenstaat były podzielone ${ }^{22}$, czego wyrazem było jedynie o tym wspomnienie w organie syjonistów „Przyszłość"23. Już na zjeździe galicyjskich syjonistów w październiku tego roku podjęto rezolucję o poparciu idei przedstawionych w książce Herzla Judenstaat a przewodniczący zjazdu, A. Salz zawiadomił listownie o tym Herzla. W odpowiedzi Herzl podziękował za poparcie. Nie mniej wspomniał, że wie o ośmieszającej notatce we lwowskim „Dzienniku Polskim”24:

Za przekazaną dla mnie bardzo łąskawą manifestację galicyjskich syjonistów składam Panu serdeczne podziękowanie Właśnie teraz ta zacheta była mi potrzebna i miła, ponieważ wyszydzająca notatka pochodząca z syjonistycznych kręgów, którą uczyniona przez „Dziennik Polski“ a przez przegląd (prasy) przez wszystkie gazety, bardzo mnie zraniła ${ }^{25}$.

Dopiero 3 I 1897 roku odbyło się w Wiedniu pierwsze spotkanie A. Salza z T. Herzlem, podczas którego lider galicyjskich syjonistów przedstawił stan ruchu na terenie Galicji. Z kolei przedstawił projekt założenia wielkiego dziennika w Wiedniu ${ }^{26}$. W trakcie spotkania omówiono także udział syjonistów w majowych wyborach do parlamentu austriackiego a także próby wciągnięcia galicyjskich kręgów ortodoksyjnych do ruchu syjonistycznego. 10 I 1897 roku reprezentowane przez Salza „Aha-

22. Jednym z powodów było pozostawienie przez Herzla do wyboru narodowi żydowskiemu miejsca nowego państwa pomiędzy Palestyną a Argentyną.

23. 29 III 1896 r. odbyło się we Lwowie spotkanie młodzieży syjonistycznej. Wzięło w nim udział około 300 osób. Byli to przeważnie studenci lwowskiego uniwersytetu. Zgromadzeni przesłali na ręce T. Herzla depeszę z podziękowaniem ,za mężne wystąpienie w sprawie radykalnego rozwiązania kwestii żydowskiej”; por. „Przyszłość”, 1896, nr 13/IV. 4 IV 1896 r. był się w Krakowie odczyt S.R. Landau poświęcony publikacji „Der Judenstaat” T. Herzla. Zgromadzenie przesłali na ręce Herzla wyrazy uznania.; por. „Przyszłość”, 1896, nr 13/IV.

24. Zarzucono mu, że stworzył gigantyczne plany odnośnie państwa żydowskiego a dotychczasowa kolonizacja upada $\mathrm{z}$ braku pieniędzy i prześladowań władz tureckich.

25. List z 28 X 1896 r.; por. Theodor Herzl: Briefe und Tagebücher, (wyd.) A. Bein, i in., Frankfurt/M-Berlin 1990, t. IV: Anfang Mai 1895 Anfang Dezember 1898, s. 149.

26. Theodor Herzl: Briefe und Tagebücher, (wyd.) A. Bein, i in., Berlin-Frankfurt/M.-Wien 1983, t. II: Zionistisches Tagebuch, 1895-1899, s. 473-474. 
wat Zion" mające siedzibę w Tarnowie otrzymało od Herzla przekazem pocztowym 5 guldenów z dopiskiem, że wstępuje do tego towarzystwa ${ }^{27}$.

6 II 1897 roku odbyło kolejne spotkanie, podczas którego obok Herzla brali udział jego współpracownicy (m.in. dr Leon Kellner $^{28}$, dr T.M. Schnirer, dr Oser Kokesch oraz Johann Kremenezky). Postanowiono, że wystawić kandydaturę prof. Leona Kellnera i dr Abrahama Salza w wyborach do parlamentu. Kellner miałby kandydować w Drohobyczy a Salz w piątej (ogólnej) kurii w Kołomyji ${ }^{29}$. Mimo nalegań T. Herzl nie zgodził się w wystawienie swojej kandydatury. W lutym nastąpiły dalsze listowne konsultacje. Syjoniści z Galicji proponowali czterech kandydatów ${ }^{30}$. Jednak uważali, że nie mają ci kandydaci szans w wyborach bez kandydowania samego Herzla. Galicyjscy syjoniści reprezentowani byli przez Salza na poufnym spotkaniu 6 III $1897 \mathrm{roku}^{31}$, gdy omawiano sprawę założenia spółki wydawniczej. Następnego dnia odbyła się pierwsza konferencja wiedeńskiego towarzystwa „Zion”, która poświęcona była zwołaniu światowego. Ustalono Monachium jako miejsce przyszłego kongresu oraz wybrano komisję organizacyjną, w którego skład weszli: Salz dla Galicji Zachodniej i Adolf Stand dla Galicji Wschodniej ${ }^{32}$. Kolejne miesiące trwały dalsze konsultacje dotyczące przygotowań do zwołania kongresu. Na wskutek protestu niemieckich rabinów zrezygnowano ze zwołania go w Monachium i zdecydowano się na Bazyleę. Ustalono, że galicyjscy syjoniści przywiozą na kongres podpisy galicyjskich Żydów z oświadczeniami o gotowości przesiedlenia się do Palestyny na wskutek akcji zapoczątkowanej przez T. Herzla ${ }^{33}$. Sam Salz wspomina:

27. Pięćdziesiat lat sjonizmu, s. 52. Do towarzystwa przystapili także: Oskar Marmorek (Wiedeń), J. Kremenezky (Wiedeń), A. Nossig (Paryż), dr Simonson (rabin z Kopenhagi) i Izak Schmelkes (rabin lwowski); por. I. Schiper, Dzieje sjonizmu na ziemiach polskich, [w:] Żydzi w Polsce Odrodzonej, (red.) I. Schiper, A. Tartakower, A. Hafftka, t. I, s. 526.

28. Leon Kellner (1859-1928), filolog, działacz syjonistyczny. Ur. w Tarnowie 17 IV 1859. Zm. w Wiedniu 5 XII 1928 i tam pochowany. Uzyskał w T. tradycyjne żydowskie wykształcenie. Studiował w Żydowskim Seminarium Teologicznym we Wrocławiu. Ukończył nowożytną filologię na uniwersytecie w Wiedniu. W 1883 doktorat. W 1890 docentura filologii angielskiej w Wiedniu. Od 1886 znajomość z Teodorem Herzlem (później bliska współpraca) i zaangażowanie w działalność na rzecz syjonizmu. 1904-1918 profesor na uniwersytecie w Czerniowcach. Po I wojnie światowej powrócił do Wiednia. Jego działa naukowe obejmują: składnię j. ang., ang. literaturę XIX i XX w. a przede wszystkim prace nad dziełami Shakspeare'a. Autor m.in.: Zum Syntax des engl. Verbums mit besonderer Berücksichtigung Shakspeares (1889), Shakspeare-Wörterbuch (1922), Restoring Shakspeare (1925).).

29. Theodor Herzl: Briefe und Tagebücher, t. II, s. 481

30. Mieliby nimi być: Salz, Birnbaum, Frühling z Krakowa i Bromberg z Tarnowa.

31. Theodor Herzl: Briefe und Tagebücher, t. II, s. 485.

32. List z 23 III 1897 r.; Theodor Herzl: Briefe und Tagebücher, t. IV, s. 212 .

33. A. Salz wspomina, że przywiózł ze sobą na kongres 10000 takich podpisów; por. Pięćdziesiąt lat..., s. 56
(Herzl) żądał, bym na kongres przywiózł tysiące podpisów Żydów galicyjskich, którzy oświadczą gotowość przesiedlenia się do Palestyny na zew Herzla (...). Na I kongres przywiozłem petycję z podpisami 10000 Żydów z Galicji, co Herzla bardzo ucieszyło (...) Kilka tygodni przed I kongresem Herzl zapowiedział mi, że a kongres mam przyjść we fraku i białym krawacie. Zapytałem: A może to być w czarnym surducie? Odpowiedź: Pan, nie! Do Bazylei zawiozłem jedno i drugie. Przed otwarciem Kongresu zauważył mnie Herzl w czarnym redyngocie. Zbliżył się do mnie i rzekł: niech Pan idzie, Panie doktorze po pański frak! $!^{34}$

W czasie I Kongresu w Bazylei (29-31 VIII 1897) okazało się, dlaczego taki strój był potrzebny. Abraham Salz, lider syjonistów galicyjskich, został wybrany II wiceprezydentem tego kongresu ${ }^{35}$. Wygłosił tam zresztą referat $O$ położeniu $\dot{Z} y$ dów w Galicji ${ }^{36}$. W trakcie kongresu ścierały się dwie frakcje. Zwolennicy Herzla stanowczo sprzeciwiali się drobnej i skrytej kolonizacji Palestyny, zanim nie uzyska się politycznych gwarancji. Druga grupa opowiadała się za dalszą kolonizacją, za którą optowała większość syjonistów z Galicji. Po długich debatach w przyjętym ostatecznie programie bazylejskim zwyciężył syjonizm polityczny Herzla. W programie znalazło się stwierdzenie:

Syjonizm dąży do stworzenia dla narodu żydowskiego prawnie zabezpieczonej siedziby w Palestynie. Dla osiągnięcia tego celu Kongres przyjmuje następujące środki:

1. Celowe dążenie do kolonizacji Palestyny żydowskimi rolnikami, rzemieślnikami i przemysłowcami.

2. Organizowanie i połączenie wszystkich Żydów w odpowiednich lokalnych i ogólnych instytucjach zgodnych z prawem krajowym

3. Wzmocnienie żydowskiego uczucia narodowego i świadomości narodowej.

4. Przygotowywane kroki mają być dla uzyskania zgody u państw, które są potrzebne do osiągniecia celu syjonizmu ${ }^{37}$.

\section{Konflikt z Herzlem}

Zaraz po odbytym kongresie galicyjscy syjoniści z Abrahamem Salzem na czele pojechali do Paryża i zakupili 9 IX 1897 roku od barona Edmunda Rothschilda grunt w Górnej Galilei pod kolonię nazwaną „Machnajim”"38. Na tym tle doszło do konfliktu

34. Tamże, s. 56

35. Protokoll des I. Zionisten Kongresses, Wien 1898, s. 164-165.

36. Ibidem, s. 21-28.

37. Baseler Programm, w: Der Erste Zionistenkongress von 1897 - Ursachen, Bedeutung, Aktualität, red. H. Hauman, Basel i in. 1997, s. 22.

38. Salz poinformował o tym Herzla listowanie i prosił o finansowe wsparcie tarnowskiego projektu kolonizacji Palestyny przez Ahawat Zion w Związku „Zion” (7 X 1897 r.[?]); por. Briefe und Tagebücher - Theodor 
Salza z Herzlem, który sprzeciwiał się doraźnej akcji kolonizacyjnej przed uzyskaniem od rządu tureckiego gwarancji swobody kolonizacji. Herzl zarzucił Salzowi, że postąpił wbrew postanowieniom kongresu, a jako II wiceprezydent był do tego tym bardziej zobowiązany ${ }^{39}$. Z kolei wiedeński „Zion” zażądał wycofania się z projektu i anulowania kupna. W odpowiedzi Salz zwołał w Tarnowie zgromadzenie z udziałem syjonistów całej Galicji, podczas którego omówiono powstałą sytuację i podjęto decyzję podtrzymującą decyzję o kolonizacji. Jednocześnie wyrażono poparcie dla działalności Herzla. Rezolucję zgromadzenia wysłano do Herzla, który odpowiedział Salzowi 26 X 1897 roku $^{40}$, powtarzając zarzuty, że infiltracja, do której dążą syjoniści z Galicji, jest zaprzeczeniem postanowień kongresu w Bazylei o pertraktacjach politycznych. W swoich pamiętnikach Herzl napisał:

Tarnowianie agitują przeciwko Komitetowi Centralnemu i przeciw syjonizmowi politycznemu. Zawdzięczają to, że wdali się ze swoim Ahawath Zion z Edmundem Rotschildem w mały interes sprzedaży gruntu. Bowiem dr Salz pojechał nie mówiąc mi ani słowa z Bazylei jako wiceprezydent kongresu do Paryża i tam załatwił coś przeciw uznanej bazylejskiej zasadzie ${ }^{41}$.

W odpowiedzi 31 X 1897 roku Salz wysłał do Herzla szczegółowe wyjaśnienie, w którym twierdził, że galicyjscy syjoniści opowiadali się od początku ruchu za syjonizmem politycznym, co zostało już ujęte w ich programie przyjętym w 1893 roku. Także znalazło się to w programie bazylejskim. Praktyczna kolonizacja galicyjskich Żydów jest nie tylko dopuszczalna, ale i jego zdaniem konieczna, aby przekonać konserwatywne masy, do których nie przemawia agitacja za politycznym syjonizmem. W końcu zaproponował, aby uznać osiedle galicyjskich Żydów jako stację próbną (Versuchsstation). Herzl zaakceptował to i przedłożył propozycję władzom syjonistycznym (Aktionskomitee), który to przyjął. 4 XI 1897 roku Herzl wysłał informację do Ahawat Zion w tej sprawie ${ }^{42}$. Syjonistom w Tarnowie udało się ostatecznie wysłać w następnym roku 16 rodzin. Administratorem kolonii został Zygmunt Bromberg.

Konflikt został załagodzony uznaniem osiedla w Palestynie za „stację próbną”. Jednak nastąpiło oziębienie stosunków, gdyż dalej każda ze stron broniła swoich racji. Pretekstem do tego był m.in. atak na polityczny syjonizm w oficjalnym organie tarnowskiego „Ahawat Zion”»33, o czym wspomina Herzl w liście

\section{Herzl, t. IV, s. 363 oraz przypis s. 679-680.}

39. List T. Herzla z 19 X 1897 r.; Theodor Herzl: Briefe und Tagebücher, s. 363-364.

40. Theodor Herzl: Briefe und Tagebücher, t. IV, s. 368. (W liście Herzl nie mógł odczytać jednego z podpisanych członków prezydium zgromadzenia. Był nim Edward Schwager; por. Pięćdziesiąt lat sjonizmu, s. 57).

41. Theodor Herzl: Briefe und Tagebücher, t. II, s. 577.

42. Theodor Herzl: Briefe und Tagebücher, t. IV, s. 372-373.

43. „Wiadomości Stowarzyszenia “Ahawat Zion”" [Mitteilungendes Ve- do Salza ${ }^{44}$. W odpowiedzi Salz po raz ostatni przedstawił swój punkt widzenia ${ }^{45}$.

Negatywne stanowisko Herzla wobec doraźnej kolonizacji sprawiło, że syjoniści w Galicji i tarnowskie Ahawat Zion stracili poparcie (także finansowe) europejskich organizacji syjonistycznych ${ }^{46}$ i w 1902 roku oddali osiedle administracji osiedli Rohtschilda. Mimo wyraźnej klęski syjonistów galicyjskich bronili swoich racji uważając, że praktyczne popieranie kolonizacji nie przeszkadza syjonizmowi politycznemu. W swoich wspomnieniach Salz pisał: Wielcy $i$ genialni prowodyrzy $i$ wodzowie narodu nie znosza kompromisów. Zapatrzeni w swój ideat, z nieubłagana siła druzgoca wszelkie domniemane przeszkody ${ }^{47}$.

Opowiedzenie się w 1898 roku Ogólnoaustriackiego Związku Kolonizacyjnego „Zion” po stronie jedynie politycznego syjonizmu doprowadziło do straty kół galicyjskich, które pod kierunkiem A. Salza opowiedziały się za praktyczną działalnością kolonizacyjną. W czasie zwołanego w Pradze w 1900 roku kongresu krajowego komitetu „Zion” dla Przedlitawii wzięli nim udział przedstawiciele 23 organizacji, w tym jedynie 3 z Galicji. Spotkanie w Pradze ujawniło, że w samym syjonizmie galicyjskim zaczęły się pojawiać różnice co do taktyki, jak i strategii działania, przede wszystkim zmierzające do określenia jego miejsca w syjonizmie światowym przy zachowaniu własnej galicyjskiej specyfiki.

\section{Zakończenie}

Tarnowscy syjoniści doprowadzili do wysłania do Palestyny osadników. Kolonia w Machnajim bez finansowego wsparcia organizacji syjonistycznych okazała się nieudanym przedsięwzięciem. Tarnowscy syjoniści z Abrahamem Salzem na czele, którzy do I kongresu ogrywali znaczącą rolę w światowym ruchu syjonistycznym, stracili swoje znaczenie. Ich działania skoncentrowały się więc na walce politycznej o kierownictwo w tarnowskim kahale a także o wpływy w radzie miasta. Działania syjonistów w mieście zmierzały także w kierunku stworzenia i rozbudowy instytucji, które przyczynią się do odbudowy państwa żydowskiego w Palestynie. We wszystkich tych przedsięwzięciach nadawać ton będą „nowi” aktywiści.

reins Ahawath Zion in Tarnów], 1898 (Tarnów), (Nr 12)

44. List Herzla z 26 IV 1898 r.; por. Theodor Herzl: Briefe und Tagebücher, t. IV, s. 457.

45. Wraz z odpowiedzią Salza z 5 V 1898 r. kończy się korespondencja pomiędzy Herzlem a Salzem; por. Theodor Herzl: Briefe und Tagebücher, t. IV, s. 708 (przyp. 3).

46. Udało im się w latach 1897-1898 zebrać 36050 florenów austr.

47. Pięćdziesiąt lat sjonizmu, s. 58. 


\begin{abstract}
Since 1896, the cooperation of Tarnów Zionists with Teodor Herzl began, although the opinions about the book "Judenstaat" were among them divided. At the congress of Galician Zionists in October 1896. A resolution was adopted to support the ideas presented in the book. In January 1897 the first meeting of Abraham Salz (leader of the Zionists in Tarnów and throughout Galicia) with T. Herzl took place, during which he stayed the state of the activity in Galicia. There were more meetings during which the world conference was being prepared. It determined among other things that bring the Galician Zionists congress signatures of Galician Jews with statements of readiness resettlement to Palestine in action initiated by Herzl. During the first Zionist Congress in Basel, A. Salz was elected as II. vice president of this congress. He gave a talk about the situation of Jews in Galicia. During the congress two factions clashed. Supporters of Herzl strongly opposed the petty and secretive colonization of Palestine before no political guarantees will be obtained. The second option was in favor of further colonization, for which the majority of Zionists from Galicia opted.

Despite the adopted Basel program, consistent with Herzl's views, Zionists from Tarnów went to Paris after the congress and bought land for a colony called Machnajim. Because of that, the conflict between Saltz and Herzl, who opposed temporary colonization, took place. The conflict has been appeased by recognizing settlements in Palestine for "test station". However, the estrangement has started, both of opponents believed in their arguments.
\end{abstract}

Key words: history of Jews, Zionism, Zionism in Tarnów, Jews in Galicia, Jews in Tarnów 